\title{
The Path of Military Power Interference in the Politics of Thailand
}

\author{
Septyanto Galan Prakoso \\ Program Studi Hubungan Internasional, Universitas Sebelas Maret
}

\begin{abstract}
Military element is undoubtedly important in order to protect a country's sovereignty. However, sometimes the functional aspect of military power can be biased, as military personnel also included in the political affairs. In some country this phenomenon happened, when military element through its personnel can become a part of government/bureaucratic mechanism. Tension is possible to rise between civil and military itself. In Thailand, military power can meddle in the country's politics through coup, even though it only runs the role to observe at first. The coup has happened for years in Thailand's modern history, noticeably started since 1932 after the revolution. Since then, military power always able to interfere Thailand's political affairs and cause the fall and change of the government. Recently, the same things happened in May $7^{\text {th }}, 2014$ when Thai military launched a coup towards Prime Minister Yingluck Shinawatra's government, and ended her spell as prime minister since August $5^{\text {th }}$, 2011. Therefore, in order to deeply explore Thailand's military's activity in meddling inside the politics, this journal will try to trackback through Thailand's history and discover the reasons and factors which influenced military power's interference in Thailand politics.
\end{abstract}

Keywords: military professionalism, Thailand politics, political interplay

\begin{abstract}
Abstrak
Keberadaan militer sangat penting sebagai sebuah elemen untuk melindungi kedaulatan suatu negara. Namun, terkadang aspek fungsional dari kekuatan militer dapat menjadi bias, apabila personel militer turut terlibat dalam politik. Fenomena ini terjadi di beberapa negara, ketika unsur militer melalui personelnya dapat menjadi bagian dari pemerintah/mekanisme birokrasi. Dalam hal ini, ketegangan menjadi mungkin untuk muncul antara sipil dan militer. Di Thailand, kekuatan militer dapat ikut campur dalam politik melalui kudeta, meskipun pada awalnya militer hanya menjalankan peran sebagai 'pengamat'. Kudeta telah terjadi dan berulang selama bertahun-tahun dalam sejarah modern Thailand, terutama setelah revolusi 1932. Sejak itu, kekuatan militer selalu dapat ikut campur ke dalam urusan politik di Thailand dan menyebabkan pergantiaan kekuasaaan. Baru-baru ini, hal yang sama terjadi pada 7 Mei 2014 ketika militer Thailand meluncurkan kudeta terhadap pemerintahan Perdana Menteri Yingluck Shinawatra, yang mengakhiri jabatannya sebagai perdana menteri sejak terpilih pada 5 Agustus 2011. Oleh karena itu, untuk menjelajah lebih dalam tentang aktivitas militer Thailand yang ikut campur dalam politik,jurnal ini akan mencoba untuk menilik kembali sejarah Thailand guna menemukan alasan dan faktor-faktor yang mempengaruhi proses intervensi kekuatan militer di politik Thailand.
\end{abstract}

Kata kunci: professionalisme militer, politik di Thailand, political interplay 


\section{Introduction}

Civil and military relation within a country is a classic problem that sustains and often leads to instability of the nation itself. Countries which undergo the transition from an authoritarian government to democracy often struggle with the democratic system adjustment throughout the years. One of the possible sources of the problem is the intervention from the military to the civilian government and it often becomes a potential threat to the country's civilian supremacy. (Diamond \& Plattner, 1996: ix) Thailand is one of the examples of a country with a weak civilian supremacy so that any problems in the country have the possibility to be ruled by military force. This condition is indicated by the presence of military institutions to intervene in the process of several policy formulation and issues regarding military roles in the country.

Actually, there is nothing wrong with the military power in Thailand. The history of the establishment of the Royal Thai Armed Forces (RTAF) as an institution of the modern armed forces showed that the military was initially founded based on the principles of military professionalism. Separation between civil and military activities for the first time even have been applied in the period of Ayutthaya in 1351 and constantly modernized as professional armed forces in the era of the reign of the Chakri dynasty, especially under the leadership of King Chulalongkorn (Rama V). (Riggs, 1967: 19-22).

However, after 1932 revolution, military interference seems has become a pattern in Thailand politics. It has transformed as an unwritten rule, when a coup should be conducted by the military in order to change the political situation. As from 1932 to 2014, the military has successfully done 18 coups since the fall of the constitution absolute monarchy. In the period 1932 to 2014 recorded 12 coups has managed to take over the government (CNN, 2014). For nearly five decades, the government is under control of military rule, as shown in the dominance of the three generals: Plaek Phibunsongkhram (19381944; 1948-1957), Sarit Thanarat (1959-1963), and Thanom Kittikachorn (1963-1973). This condition was not without any challenge at all, as between 1932 to 2006, there were two times of mass demonstrations demanding the decline of military regime in 1973 and in 1992. Revolution 1973 is considered an important momentum that started the reform of civilmilitary relations in Thailand, driven by the strength of students in 1973. The revolution succeeded overthrowing the military regime of Thanom Kittikachorn and brought Thailand to the establishment of democratic parliamentary government for three years before 1976, when a military coup (with the involvement of violence) end it. Another movement against leadership of the military regime in 1992 succeeded in overthrowing the military government of Chatichai Choonhavan, and also remarked the critical period for the demilitarization process and enforcement of civilian supremacy in the period of fourteen years, until the military coup in 2006.

From the investigation through history, it is clear that the military interference in Thailand is rooted in the Thailand politics. It is also obvious that the pattern and background are repeating from time to time, when the military considers the civilian politicians are incompetent in the management of the state and there is a severe political instability. The military power in Thailand has the authority to control the political activities of civilian politicians, especially when it threatens the security and stability of the Kingdom of Thailand. Moreover, most of the moment, the King gives his blessing towards the military involvement. This condition obviously becomes an advantage for the military power in Thailand to keep meddling in politics. However, military power seems avoiding the "main stage" in every intervention/coup. Everything is done as if the military has the mission, which given by the King himself, to save the country. There are also other factors which causes the military power choice to 'step aside' from the main stage, besides the presence of the King. Constitution, people's protests, and the political parties' battle may become some of the factors.

Suspicion grows in the modern era, why Thai military continues to meddle in politics, when the democracy has just started to ran smoothly in Thailand? From the observation towards 1997 constitution, there 
was no particular problem for Thailand democracy, as it was created with the active and fair involvement of the people, and also through democratic procedure. Yet, the 2006 and 2014 coups still happened. This situation led to an analysis about the democratic value in Thailand, which is apparently only used as a mask to cover the King's absolute rule system with military force. As a matter of fact, the people of Thailand still have a strong culture where feudalism was on the highest authority of the King. This condition somehow explains why the application of democracy in Thailand is hard to do. Every background of the military coup always go with the incidental reason with the basis objectives is to maintain the security of the state, because of civil government's incapability to handle the situation in the country. This situation certainly considered as a waste in Thailand politics, because actually in the modern era, Thailand has done some effort to move the direct military involvement in politics to the backgrounds, remarked with the increasing number of Thailand leaders who have civil background.

Some experts already conducted some researches regarding the intervention of military into politics in the case of Thailand. It also highlights the fact that the military is somehow superior on certain aspects, was already become a common sense in Thai people's mind:

Political supremacy of the military has been an outstanding feature in the modern Thai political system since 1932. An absence of strong participatory political institutions and a lack of legitimacy on the part of civilian regimes enable the politicised military to seize power and establish an authoritarian regime without much difficulty. (Samudavanija and Bunbongkarn 1986, 114)

It can be underlined that a coup happens when military element still see themselves as the most merit pundit to control Thailand. The lack of civil participation in politics also sustains that argument, even when civil supremacy has already progressed through years. Yet, a coup is still and likely always possible to happen.
An analysis using the concept of military professionalism and bureaucratic polit will be used in elaborating the development of the military power interference in Thailand politics after 1932 revolution, with an additional point from civil supremacy concept. An argument can be developed here, as military involvement/interference in Thailand politics from 1932 until this current era can be described as an implementation of a new professionalism of the military power itself, which capable to run the duty of securing the country and running the development at the same time. This condition also affected by the bureaucratic polity system which placed Thailand's military power as an important element in Thailand politics for years.

This article will have some steps to examine the reason of military interference in Thailand politics: first step is to trackback the Thailand history, and to explore the relation between politics and military power in modern Thailand; second step will conduct an analysis to discover the reasons for the military power in Thailand to interfere in politics; third step will underline the fact that the role of military in politics somehow did not take the main stage; and last is the conclusion.

\section{Politics and Military Power in Thailand \\ - $\quad 1932-1973$ \\ In June 21 st $^{\text {st }} 1932,46$ military} personnel and 65 civilians were successful in launching a coup against the absolute monarchy of Thailand. The event was known as 1932 revolution, which was done by the civilmilitary group who called themselves Khana Ratsadon or 'People's Party'. This group of people asked King Rama VII (King Prajadhipok) to agree on the creation of the constitutional government. Basically, the main reason of 1932 revolution is the needs of democracy, as King Prajadhipok government was judged to be unfair towards the people. Still, there are three possible reasons for the revolution for took place. First, the declining power of the monarchy government, as King Prajadhipok considered being as not as good as his predecessor. Second is the emergence of the 'educated' civilians who were disappointed about the current condition of the country in that era. The disappointment pushed them to 
form a revolutionary group, and later on developed into People's Party with the assistance from the military. Third, some policies created by King Prajadhipok endangered the economic stability and the employment in that time. The King decided to cut the wage budget of military personnel and civil servant. (Siffin, 1966: 17-18). Moreover, King Prajadhipok also implemented the Civil Service Act in 1928 which has the objectives to reduce the personnel of military and civil servant. This situation made all of Thailand people disappointed at that time, including military personnel. These three factors became the main consideration for the People's Party to commence their objectives in turning down the absolute monarchy government. When the momentum came, the coup was succeeded and thus become a new start for Thailand under a constitutional government.

In the beginning, the monarchyconstitutional government was not running smoothly. Despite the establishment of 1932 constitution, a lot of conflict occurred inside the elites in Thailand. During this period, the military power gained a lot of sympathy from the people because of their role in 'keeping the constitution'. One of the core events was the military actions to defeat Bowaradej Rebellion, a rebel movement which against the constitution and supported by the royalists of the King, in Bangkok. This particular event also boosted Phibunsongkram's popularity, which later helped him in securing the position of the Prime Minister in 1938.

Phibunsongkram was excited to highlight the importance of nationalism, patriotism, and militarism, for the new identity of Thai people. In his view, monarchy institution, the parliament, and also the cabinet of the government would not be able to coexist without any assistance from the military. ${ }^{1} \quad$ Basically, Phibunsongkram's government became the blueprint of the other Thailand military governments in the upcoming era, as his government can sustain with the support from the military power, the good image caused by stability of Thailand security in regional (against the threat of

${ }^{1}$ Phibunsongkram's ideas were quite easy to be campaigned, as the People's Party remained the only territory claim by surrounding countries), and also the support from Buddhist monks as the religious element in Thailand society.

After the first Phibunsongkram era, Pridi Phanomyong became the prime minister. The death of King Ananda Mahidol and the domestic economic crisis made him resign in 1946, and the chaotic state of Thailand politics called Phibunsongkram back in 1947, when he proceed with the coup against the civil government. One of the reasons for the coup is to protect the concept of "Nation, Religion, and the King", in the midst of communism threat and domestic instability because of the murder of the King (Phongpaichit \& Baker, 2002: 286). The second regime of Phibunsongkram was not as stable as the first, with some coup happened, and also the opposition attacks (Democrat Party). This situation resulted in Phibunsongkram's fall in 1957, by the successful coup led by Sarit Thanarat. In Sarit regime, Thailand's development increase significantly, even though Sarit's applied absolute military regime and forbid all public aspirations, he has done a good job in improving Thailand economy. However, most of the capital came from United States, as Thailand agreed to follow anti-communism movement as one of U.S agenda. In Vietnam War, Sarit's Thailand supported the U.S. Army, and as a result, U.S Army sent financial assistant for Thailand which the amount is up to \$20 Million (Phongpaichit \& Baker 2002, 294). When Sarit died in 1963, Thanom Kittikachorn was appointed by King Bhumibol Adulyadej to become the prime minister. During that time, he prefers to continue the policy from Sarit's regime (Nuechterlein, 1964: 846-847). The weakness of Thanom's regime lied on the unawareness of the student's union power. The peak of the conflict is that the military government failed to protect the legitimacy against the revolt in 1973. However, after three years time, the military power was back and did another coup, based on the reason that the democratic government cannot surmount the current instability in Thailand, and to protect the existence of The Kingdom. As a result, The King support the successful

party in Thailand politics at that time. (Sukatipan, 1995: 197.) 
coup in 1976 , and this condition remarked the military power interference in Thailand politics from 1932-1976.

\section{- 1976-2001}

The military interference in politics from 1976 until 1990 s was different from 19321976. With a lot of civil intellectuals, military power has faced a challenged it has never met before. There were also some of coup happened in this era, for example in 1977 and 2001. For 1991 case, this ignited another big event in Thailand political history, which was the Black May in 1992. In responding of the mass demonstration, the current prime minister in that era, Suchinda Kraprayoon preferred to use armed force. On 17 and 18 May 1992, units of the Armed Army under the command of General Issarapong Noonpakdi used strategies phairi phinat (crush opponents). The result was horrible, from 17 May until 20 May, there are 52 died and more than 3500 protesters were captured. In the end, King Bhumibol instructed Suchinda to end the conflict by stop the violence. ${ }^{2}$ After that, Suchinda and the other military general of the current regime decided to withdraw the army from the street. This incident also caused Suchinda to resign from the position of prime minister.

After 1992, there were pressures against military position as an influential force in politics. The military power of Thailand is encouraged to re-run a professional role in the field of defense. It can be said that during that time, military was experiencing a phase change on the political role in government. The opposition towards military interference in politics was followed by the growing influence of democracy and enforcement of civil supremacy. Moreover, when Chuan Leekpai elected prime minister from in 1992, a series of policy reforms have been successfully implemented to reduce the military rule in politics, including the use of military force in controlling riots, which must be authorized by the cabinet. He also reduced military spending as the impact of the financial crisis that hit
Thailand in 1997. The peak of the progress in reducing the military interference is remarked by the establishment of 1997 constitution which limits the movement of military power in politics quite effectively since 1932. In 2001, Chuan Leekpai he was replaced by Thaksin Shinawatra.

Democratization process with the civil-driven government since 1992 has successfully implemented a number of institutional changes needed to reduce military interference in Thailand politics. The military conducted a series of stages reforms aimed to restore the role of the armed forces as a professional defense guards in the country. However, this condition did not automatically end military interference towards Thailand politics, as another coup happened in 2006, causing Thaksin's government fell.

\section{- 2006 onwards}

The coup in 2006 used a lot of basis to tackle the Thaksin's government. Starting from the loss of trust from the people, the economic policy blunder (the selling of Shin Corp. to Temasek Building), corruption in bureaucracy system, the 'duel of popularity' between Thaksin and the King, and so forth. On top of that, 2006 coup indicated that the military power will always interfere in Thailand politics. Moreover, if there are a lot of motives to tackle down the civil government. In 2006 case, the momentum was good for the military side, as the King also support the coup, for the sake of balancing the nation. Jump to 2008, the crisis in political sector inherited from 2006 caused Samak Sundavarej to resign from the position of prime minister. He was succeeded by Somchai Wongsawat. In this case, these two people are Thaksin's acquaintances. Finally, the 'change' in Thailand politics completed when Abhisit Vejjajiva became the prime minister in 2008, by parliamentary vote. However, Abhisit also was not too successful in maintaining his governance, as he lost to Yingluck Shinawatra in 2011 general election. This event also indicates that the sympathy

\footnotetext{
${ }^{2}$ In 1992 The King decided to end the use of excessive armed force as it will damage the image of a new democratic Thailand. (Bunbongkarn, 1993: 220.)
} 
from Thai people (especially in Northern part) towards the Shinawatra family is still strong until today. During all of the political chronicles, the military still play the background role mostly through the Privy Council, observing the mistakes or loophole in the current civil government.

The history repeats itself in 2014 coup, when again, a Shinawatra family member was forced to step aside from the position of Prime Minister. Yingluck Shinawatra's political opponents wish was fulfilled when military take over the government. The reason to go against Yingluck was ignited after her intention to push an amnesty bill for his exiled brother Thaksin, so that he may enters the country again. The question is, is that really the reason? There is definitely a theory which views this condition as an old hatred between some stakeholder against Shinawatra family. In this case, military has the possibility to become the executor or the provoker, or both. Hence, the 2014 coup is considered as a 'silent coup' as the people in Thailand do their daily activities as usual, with some 'adjustments' considering the curfew and another coup-effect order from the military.

It can be understand that actually, Thailand military power is very professional at first, as they have their own institutions, and was not involved in any political affairs. However, the condition in 1932 made the military power of Thailand thought that they were the most merit side to run the government.

\section{Reasons to Interfere}

The reasons of military interference can be elaborated through the concept of military professionalism and bureaucratic polity. In addition, some part of civil supremacy also important to be added. Start from the military professionalism, Samuel Huntington argued that involvement of military in the area of politics is a violation of the military code of professional ethics and indicates the "political decay" in the governance. Military roles and missions outside the profession is a form of decreased military professionalism. Huntington argued that the military institution and professionals must meet three criteria of a professional military, namely: expertise (skills), social responsibility, and corporate spirit or esprit de corps. The characters of professional military will gave birth to the ideology of "military mind" as an ideology that contains recognition for professional military from the civilian government. (Huntington, 2003: 79)

Towards this 'military mind' ideology, Gene Lyons said that:

\begin{abstract}
"There is a military mind and all military men, to one degree or another, possess it. It is a mind that is used to order and predictability, that insists on decisions being made, that cannot tolerate procrastination, that is comfortable in the manageable world of a military post and often unconsciously makes over any other setting - the home, the office, even presidency of the United States - with the same characteristics of punctuality, rank and simplicity. (...) The military mind is largely a product of the military system, the repetitious training, the requirements of obedience, the instilling of assured responses to known stimuli, and the development of trust through respect for position and hierarchy." (Tromp, 1971: 361)
\end{abstract}

Two views above indicate that as trained and professional personnel, the military powers must stay in their duty as assigned. However, there is also another view by Alfred Stephan and O'Donnell, called new professionalism, stating that the military as a means of national defense must be able to be aware of the forms of threats both external and internal. This shift in orientation professionalism motivated by the involvement of states and non-communist countries communists in "total war." In this war, the threat facing not in the form of an external threat, but the threat of war against communism movement, revolution in social system evolved because of the downturn, economic, and politics in developing countries. According to professionalism in this new paradigm, strategies which are needed to win the war are closely related to national security and national development which spawned "new professional army" to win the 'total war', (Stephan, 1976:244-260) as stated: 
"The days of the "old professional soldier" who had fought conventional wars with external enemies were almost over. The "new professional soldier," trained in fighting a "total war" with the internal enemy on military, social, economic, and political fronts, was the prime needed. Because civilian leaders did not have the requisite skill and organizations to fight the new war. It became the manifest destiny of the "new professional soldiers" to establish control over all aspects of society, bring about rapid socioeconomic development, and win the glory of defeating the great threat to Western civilization." (Maniruzzaman 1978, 1011)

Alfred Stephan himself also said that:

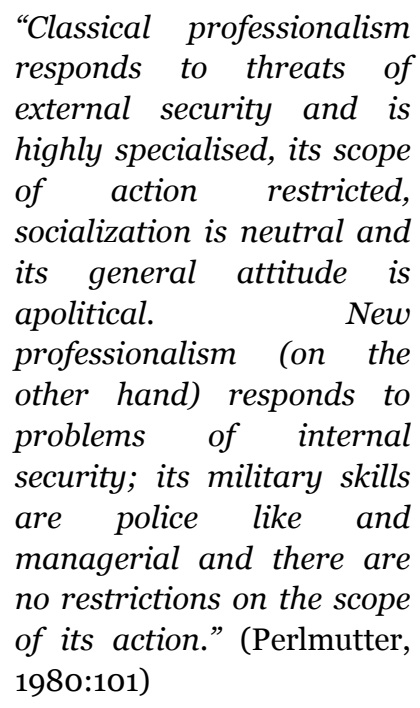

Conventional professionalism faces external security challenges and response with clear boundaries, while the stance is neutral, and apolitical. Alfred Stephan calls the new professionalism as a form of professionalism that is not only directed toward external defence and military use as a tool of foreign policy but also should be related to domestic security and development (Stephan, 1973: 47$65)$.

In the case of Thailand, it can be seen, somehow that the military involvement/interference in Thailand politics from 1932 until this current era can be described as an implementation of a new professionalism, whether it came in the correct application or not. In the principal of new professionalism, military power is capable to run the duty of securing the country and running the development at the same time. A political instability also can be classified as a threat towards the nation security; in this case the Thailand military power represents a suitable case study for Stephan's approach. Even if the so called 'total war' will not happen, the importance of national security and national development may become a good basis of reason (or justification) for the military power of Thailand to meddle in politics.

This condition also affected by the bureaucratic polity system which placed Thailand's military power as an important element in Thailand politics for years. Since 1932, a strong, encapsulated system of government, which only includes the elites (both civil and military regimes) made Thailand late to learn about the step towards a healthy democracy. Such lesson occurred in the form of tragedy, respectively in 1976 and in 1992. A unique situation happened when Thailand transformed into a democratic country. The uniqueness is located in the core of the government itself, as it basically also being hijacked by the oligarchy (businessmilitary relation). Any extra-bureaucratic organization seemed too weak to challenge the oligarchy power. The absence of control towards the ruling power made the government is very fragile towards the practice of corruption and nepotism. Bureaucratic polity also left a deep sense of 'patronage' in Thailand politics. With the senior and experienced individual (both civil-business and military) became the patron, it is very hard to step against the unfairness in the politics. Especially for the military power in Thailand, with the strong hierarchy-based principal of command, the patron concept support the idea that the military power of Thailand is the savior of the nation, when any instability happens.

These two factors, also collides with the absence of civil supremacy in Thailand. For years, the people in Thailand cannot do anything towards the power of the military. There were developments, as demonstrations and protests happened. Still, the power of the military remains unchallenged, as the King and 
some political party also supports the military in many occasions.

\section{A Peripheral Stage}

It started to become obvious since 1973, when the interference of military power was not being the main stage. Back then, Thai military became thoroughly discredited in political arena (Ockey, 2001: 199). The best reason to explain this situation is because of the people of Thailand was already aware of the method to practiced democracy in a nation. This statement can be proved by the evidence of the history, when the student-led mass demonstration was succeed in change the wind of the politics (although only stayed for a short time). Hence, more important impacts emerged after that incident, as more extrabureaucratic organizations were starting to balance the power of the military.

The other factor is rooted in the principal of Thai people, 'Nation-Religion and the King'. This principal main highlight is in the last part, which placed the King as an important, yet fixed element. Whatever the current condition of the nation, and even if the religious institution cannot surmount the problems which existed, as long as the King is present, everything will be fine in the end. The presence of The King is indeed become a vital factor to prevent the total domination from military power when the interference happen. Sometimes, the King even can decide whether a coup is needed or not, based on the current condition and relation with the military and other parties (business and political parties). This fact underlined that the role of the King in the current era overwhelms the power of the military in politics.

In some years, Thailand constitution also limits the movement of military power in politics. However, in most of the cases, especially in 2006, these constitutions were being dismissed by the ruling power (military) after a coup. Besides constitutions, the focus of Thailand politics cannot be moved from the battle between parties. As the time goes by, there are a lot of new parties which challenge the old-power parties like Democrat party. This is why the military power cannot take the main role in politics, either when there is interference, or when there is not.

\section{Conclusion}

The future challenge for Thailand is basically simple, as Thailand has to choose which path of democracy to take. If they choose to maintain the status quo, there is no guarantee that there will be no more coups. As long as the system stays like the current era, Thailand politics can be attacked by other coups. The Kingdom of Thailand must clarify the most suitable system in order to create a stable and firm government. One of the efforts that can be done is that the government, along with the military power must set a rule which separates the function of military power from politics. This set of rule can be included in the next constitution which has to be protected by the King. At the end of the day, the rule of the King is still needed as the guardian of the nation. This is also need to be done, so that there will be no more constitutional dismissal. Thailand military also will not take more active role like in the past because of the presence of the King, and also the political nature in Thailand, which highlights the tension between the ruling party and the opposition.

However, this is also add the quantity of challenges, as the King sometimes plays in the political interplay between with the military, and the people of Thailand themselves. In the past, the King was weak, but somehow as the time goes by, the presence of the King grew stronger, as the King himself can endorse the coup for certain objectives. This condition may happen because of the root of Thai culture itself. When the King is still exist and respected, no one can go against him. It is also become the sources of political interplay between the parties who want to take the benefit from the King position.

Another challenge is that the military power is already overwhelmed, not only in army forces sector, but also in business activity. This condition indicates that Thailand military power somehow represent their own interest. In some cases, like what happened in 2006, the military seems capable to drive the media against Thaksin, by the power of connection and business.

In the end, Thailand military power will keep interfering in the politics (even though it does not take a centre stage) because of the complex combination of historical 
factors, wrong approach towards democracy, and the presence of the King. A form of new military professionalism was included in Thailand case, as the basis for the interference, which is also sustained by the bureaucratic polity, and the absence of civil supremacy in Thailand.

\section{Bibliography}

\section{Books}

Diamond, L \& Plattner, M.F., (1996) CivilMilitary relations and democracy. Baltimore: JHU Press.

Huntington, S.P., (2003) The soldier and the state: the theory and politics civilmilitary relations; Bahasa Indonesia Edition, Prajurit dan negara: teori dan politik hubungan militer-sipil. Translator: Deasy Sinaga. Jakarta: PT. Grasindo.

Maniruzzaman, T., (1978) Military withdrawal from politics: a comparative study. Massachusetts: Ballinger Publishing Company.

O'Donnell,G., (1976) Modernization and military coups: theory, comparisons and the argentine case. In Lowenthal, A.F, ed. Armies and politics in latin america. New York: Holmes \& Meier.

Ockey, James., (2001) Thailand: The struggle to redefine civil-military relations. In Alagappa, M. ed. Coercion and governance: the declining political role of the military in asia.

Stanford:Stanford University Press, pp.187-208.

Phongpaichit, P. \& Baker, C., (2002) Thailand: economy and politics. New York: Oxford University Press.

Riggs, F.W., (1967) Thailand: the modernization of a bureaucratic polity. Honolulu: East-West Center Press.

Samudavanija, C.\& Bunbongkarn, S. (1986) Thailand. In Ahmad, Z.H. \& Crouch, $\mathrm{H}$. eds. Military-civilian relations in south-east asia. Kuala Lumpur: Oxford University Press, pp 78-117.
Siffin, W.J., (1966) The Thai bureaucracy: institutional change and development. Honolulu: East-West Center Press.

Stephan, A.ed. (1973) The new professionalism of internal warfare and military role expansion. Authoritarian Brazil: origins, policies, and future. New Haven: Yale University Press.

Stephan, A., (1976) The new professionalism of international warfare and military role expansion. In Lowenthal, A.F. ed. Armies and politics in Latin America. New York: Holmes \& Meier.

Sukatipan, S., (1995) Thailand: the evolution of legitimacy. In Alagappa, M. ed. Political legitimacy in Southeast Asia: the quest for moral authority. California: Stanford University Press.

Tromp, H.W., (1971) The assessment of the military mind: a critical comment on methodology. In Van Gils, M.R. ed. The Perceived Role of the Military. Rotterdam University Press, n.p.

\section{Journal Article}

Bunbongkarn, S. (1993) Thailand in 1992: in search of a democratic order. Asian Survey 33( 2), A Survey of Asia in 1992: Part II, February.

Nuechterlein, D.E., (1964) Thailand after sarit. Asian Survey, 4(5), May.

Perlmutter, A. (1980) The comparative analysis of military regimes: formations, aspirations, and achievements. World Politics,33(1), October.

\section{Online Article}

CNN. (2014) Thai military takes over in coup - again [Online], available from: < http://edition.cnn.com/2014/o5/22/ world/asia/thailand-martial-law/> [Accessed 22 May 2014] 
